\title{
Charities Reform in Australia
}

\section{Gary Johns}

\begin{abstract}
A ustralia has a large investment in altruism. There are over 50,000 charities in Australia (Australian Taxation Office, 2001), supported by about onethird of individual taxpayers, worth nearly $\$ 3$ billion (Centre of Philanthropy and Nonprofit Studies, 2004:1) every year. Australian donors do not know if their investment in altruism is wise. They do not have the information to judge whether their donations are put to best use. Measures of performance are available for investors in the corporate sector, and for voters in the government sector. They should be available for donors who support the charity sector.

As an acknowledgement of the growth and importance of charities, the sector has sought to expand the definition of charity in terms of both purposes and the means by which they are achieved. It has also sought regulatory reform, including the establishment of a Charities Commission. To date, the Australian government has accepted an expanded range of charitable purposes, but has not clarified what constitutes acceptable charitable activities. It does not appear willing to engage in regulatory reform, including the establishment of a regulator for the sector.

A key principle of charity reform is whether charities inform their donors sufficiently well of their activities. Charities have a case to answer that they do not keep donors well informed, an especially important issue when charities are claiming a larger role in the distribution of government resources and in advocating public policy. The paper discusses a proposed model for charity disclosure aimed at achieving an informed donor market. The model is designed to provide a powerful tool for scrutiny as well as a guide to acceptable purposes and activities. The paper argues that the government should assist the sector to achieve the standard of disclosure suggested, and establish a dedicated regulator.
\end{abstract}

\section{What is a Charity?}

Charities operate for a wide array of purposes and in any number of ways. The Australian Taxation Office uses the generic term 'not-for-profit' (NFP) to cover the range of organisations that receive tax assistance. The NFP generic consists of charities, health promotion charities, and public benevolent institutions, and encompasses entities such as welfare providers, hospitals, universities, and a myriad of others. These variously have access to tax concessions in income tax, fringe benefits tax, Deductible Gift Recipient Status, Goods and Services Tax, refunds of Imputation Credits, and a range of state government concessions such as stamp duty, payroll tax, land tax, and debits tax. For the purposes of the discussion the term charity will be applied to any NFP that benefits from public support through the taxation system because the term charity carries the most 
powerful and familiar connotation of 'doing good'. Each of the entities has achieved their 'charitable' status more by the intention to do good works, than by any proof that they in fact do so. Moreover, the range and nature of objectives and activities undertaken in the name of charity has expanded enormously in recent years. For example, The Australian Conservation Foundation, Friends of the Earth, Greenpeace, and The Wilderness Society are 'environmental charities'. This may surprise those who understand charities to be predominantly working to help the sick and the poor.

Moreover, some charities are very active in government. For instance, the Queensland Conservation Council boasts 60 representatives sitting as environmental consultants on committees throughout the state. Even those that help the sick and the poor want to do it differently, they want to overcome inequality. Russell Rollason (2003) of Anglicare asked: 'Is the role of charities and churches simply to apply band aids to the victims of our competitive society or should charities actively contribute to a fairer more just Australia?' Indeed, the way charities go about their business can raise doubts as to the purpose of their charitable activity. A very astute question by Senator Brandis, the Chair of the Senate Economics Legislation Committee on this issue, 'is the purpose [of the charity] attenuated by the mode of advocacy?' elicited the following response by the Commissioner of Taxation: 'It may well be' (Senate Hansard June 3, 2004).

There is an assumption in the public support of charities that a donor understands the purpose of the charity. When the charity's methods are direct giving aid to the poor, planting trees, and writing letters to foreign governments on behalf of political prisoners - the task of informing the donor is not great, because the purpose is unambiguous. As the methods and definition of charities widen however, the assumption of donor knowledge may not hold. Consider these examples:

- A welfare charity no longer solely gives aid directly to the poor, but uses its resources to argue that the tax system achieve equality. It is debatable whether lobbying government in the pursuit of an egalitarian ideology through more generous unemployment benefits or a more progressive tax system - constitutes charity for the poor.

- An environmental charity that lobbies government to tax hydrocarbons may not be performing a public benefit. It is just as likely to be pursuing an environmental ideology based on assumptions of resource depletion.

- It is debatable that a human rights charity that lobbies for the International Criminal Court is pursuing little more than an anti nation-state ideology.

In these ways, and many others, lobbying by charities is meant to divert public resources to their favourite cause. Charity work is no longer unambiguously good, or for the public benefit. It may be altruistic, but increasingly it is embedded in a political framework that seeks to use public power for system change. These methods are unambiguously political in nature. Arguably, it is at odds with the donating public's expectations of the charities. 
There is another class of behaviour that may also be at odds with public expectations. Where charities compete with private providers to deliver government services, for example, domestic welfare and employment services or foreign aid services there may be an unfair advantage awarded the charity. The government, or the donating public, may be comfortable with such an advantage being granted, but it would be more equitable if the advantage was known and conveyed to the donor, which at present appears not to be the case.

These debates would not matter so much if charity status did not carry taxassisted privileges and if donors were well aware of the work of charities. As charities are publicly assisted, and as it is unlikely that donors are fully aware of their activities, there is a need to scrutinise the activities of charities. This already takes place in two respects. Charities are subject to state laws governing their fundraising, and they are registered under the Taxation Act and therefore have to prove their purpose, for example, to be publicly beneficial. The proof required to gain a tax-advantaged status is minimal and almost none of the relevant legislation aims to keep the donor well informed. For the purposes of the donor making an informed decision, the regulation is wholly uninformative.

\section{The Donor as Regulator}

There are two concepts of charities' behaviour that may be useful in understanding the need to inform donors. First, charities raise their funds by acting as agents in pursuit of the donors' wishes. Second, charity advocates seek to raise funds from donors to further the cause most dear to the heart of the advocate. Donors need sufficient information to decide if the charity is an agent or an advocate or, if both, in what proportion. The donor has the power to withdraw support if dissatisfied with the charity's performance, but a continuing interest only arises with continuing donations. It is a weaker power than that of shareholders who can sell their part in an enterprise if dissatisfied with its performance. Such power as the donor has is best used when based on good information (for example, evidence of the fulfilment of the charity's mission). While an essential element of disclosure is the charity's mission statement, so also is evidence of the mission's completion. Did the charity do what it promised? Did it fulfil its mission in the most efficient way? Measures of efficiency and effectiveness would aid the donor in deciding how, or indeed whether, to spend their money.

From the donors' point of view, there is a gaping hole in the scrutiny of charities. The present scrutiny does not provide an answer to the question: are charities any good at what they do? In the stockmarket, there are those who analyse corporations and advise investors. There is a market in information. In the donor market, there is no incentive to analyse the performance of charities because the 'investment' by the donor is usually insufficient to warrant the cost of advice. Consequently, there is no money to be made in analysing charities. In the case of large philanthropic donors, such as foundations, who may be willing to pay for information, the notion of a 'return' on the donation has either been eschewed, or subsumed by the emotional response to the cause. They do not appear to want 
to know the answers to the crucial questions of performance, or if they do, they gather the material for their own use, and are under no obligation to inform other donors. Such attitudes also prevail with respect to accountability requirements for foundations (Leat, 2004). Furthermore, these donors are in much the same position with respect to charities as are institutional investors to public companies. Many philanthropic donors have representatives on the boards of the beneficiaries of their gifts, so they may be reluctant to enforce a set of disclosures that would allow other donors to make a judgement about the performance of their charities.

There are organisations that keep an eye on charity performance. For example, Givewell gathers material on the fundraising costs of charities and other relevant material. The difficulty is that it can only list information that is available, most of which is incomplete or not comparable. An example of a website where many charities' activities can be viewed is Donations.com.au. The service 'streamlines the fundraising activities' of the donor by depositing directly into the bank account of the selected organisation. There are, however, no data whatsoever to make a judgement about the efficacy of the organisation. The decision to donate is based on the emotion of the cause. The donor's trust in the charity is assumed. The Australian service may be compared with one based in the USA (Give.org) which for many years has established and scrutinised standards of disclosure by charities. The Australian Consumers' Association (ACA) attempted a survey of charities in 2002, seeking to answer the question: 'Which ones are worthy of your generosity?' The ACA abandoned its attempt to rate the worth of charities, concluding (ACA, 2002):

Unfortunately, charities don't have to comply with any uniform standard for presenting their financial reports. That means the way they break down income and expenditure can vary, [and] it's difficult to exactly compare one charity against another.

An attempt to understand the extent to which a donor may use published information on performance to decide to support a charity has been made by the Charity Commission for England and Wales (2004a). Using a recent survey of public attitudes in the UK, the results show that:

- the public considers the principles of transparency and accountability to be important;

- $\quad$ information about the areas of activity on which charities have spent their money was considered the most important; and

- $\quad$ sixty per cent of respondents said that the ability to compare important information between charities would affect their decision about which charity to support.

Similarly, a survey of Canadian opinion conducted on behalf of the Muttart Foundation (2004:5) has indicated that Canadians place a great deal of importance on receiving information about charities and the work they do, and 'almost all 
respondents indicate that it was important that charities provided information on how they use donations, their fundraising costs and the impact of their work.'

In Australia, each state has its own laws governing public collections and fundraising. The terms and requirements of the various Acts vary quite significantly, as does the way they are interpreted. For example, in NSW and Victoria, the Acts relating to charities require them to disclose their fundraising income and expenditure. Givewell's research, however, has shown that the rate of adherence to those requirements - though better in NSW - is quite variable in both states. Similarly, a study by the Institute of Chartered Accountants in Australia (ICAA) analysed the financial and annual reports of 22 major NFPs in matters such as the disclosure of fundraising costs. Using the NSW Charitable Fundraising Act 1991 as its measure, it found that only four of the reports included data to comply with the requirements of this Act. The ICAA report also found that only three of the 14 NFPs 'who would have incurred a deficit without a government grant', included in their financial report disclosure of this crucial information (ICAA, 2003a:25). Although meeting the requirements imposed by Federal and State legislation in general terms, the ICAA review found that the reports of most NFP organisations did not satisfy the needs of two of their key stakeholder groups, the donor and the funding provider (ICAA, 2003b).

More disconcerting is evidence of reluctance in the sector to disclose relevant facts about their activities. A recent survey of regulatory issues in the NFP sector found that, 'a startling nine per cent of respondents thought that no information should be made available to the public, while only 39 per cent agreed with fully audited accounts being disclosed (as is currently required by the Corporations Act), and just over half thought summary financial information should be enough' (Woodward and Marshall, 2004:2). The Australian Taxation Office (ATO, 2001:26) has argued that 'if more information on concessionally taxed bodies was made publicly available ... the public and organisations could more easily bring non-compliant behaviour to the ATO's attention, or other relevant agency'. The issue is: what kind of information? In an increasingly politicised sector, keeping donors well informed may require the public disclosure by charities to donors of three things - the efficiency of the charity, the nature of the work undertaken in the name of the charity, and the achievements of the charity. Donors may have little voice in the charity, but, armed with good information, they would have the power of spending their donor dollar elsewhere.

\section{Modest Reform So Far}

A number of major studies of, and inquiries into, the charity sector in the last decade have recognized the important work of the sector, but also its variable legal form and difficult-to-define boundaries. An inquiry undertaken in 1995 by the Industry Commission (IC, 1995), Charitable Organisations in Australia, provided some very good data and sound recommendations as to how the sector may be better regulated. A second inquiry, the Charities Definition Inquiry (CDI, 2001) sought to define a charity better. Its recommendations are contained in Report of 
the Inquiry into the Definition of Charities and Related Organisations. In submissions to the Charities Definition Inquiry, the sector sought to expand the definition of charity work (Australian Environment Organisations, 2001:1), and reap the benefits of an 'independent' regulator (Australian Council of Social Services, 2001:3). The Industry Commission recommendations have been largely ignored. Instead, a lesser raft of changes arising from the Charities Definition Inquiry has produced modest change.

The Australian government introduced the Charities Bill 2003 in an attempt to define charitable activities better. The Bill was withdrawn, however, after advice from the Board of Taxation in December 2003 that it 'failed to achieve the level of clarity and certainty' that was intended (Board of Taxation 2003). Having failed in its attempt to introduce a legislative definition of a 'charity', the Government decided to continue to rely on the common law meaning. The only change was to extend the definition 'to include non-profit child care available to the public, self-help groups with open and non-discriminatory membership, and closed or contemplative religious orders ' (Commonwealth Treasurer, 2004).

In addition, legislation was tabled in Parliament on 19 February 2004 requiring charities, public benevolent institutions and health promotion charities to be endorsed by the Tax Commissioner in order to access relevant taxation concessions. The amendments extended the endorsement processes currently undertaken by the ATO to all taxation concessions, to which charities, public benevolent institution and health promotion charities are entitled (ATO, 2004a). The changes updated the list of charities, but the same method of self-assessment - 'It is your responsibility to advise the Tax Office if you are no longer entitled to endorsement' - and hands-off regulation continue (ATO, 2004b:31). In other words, the entire focus of reform has been in taxation compliance, with little regard to informing the donor of the activities and performance of charities.

\section{A Standard of Disclosure}

The major parts of the reform agenda - the need for a sound basis in regulation and a much better set of indicators of performance - remain to be addressed. In these regards, the Industry Commission Report recommendations of 1995 (IC, 1995) provide a guide, as do two further substantial studies. The ICAA (2003) review of financial and annual reports of 20 major non-profits in Australia, which recommended a specific financial reporting framework and standard, and the University of Melbourne Centre for Corporate Law and Securities Regulation 2004 study (Woodward and Marshall, 2004), which recommended the need for uniform regulation and comparable standards of disclosure.

The Industry Commission (1995:xxiii) argued that donations to charities deducted from a donors' income for tax assessment purposes,

can lever greater funds ... from the public than are forgone in tax revenue. So it can be an efficient, though indirect, means for the Commonwealth government to fund [charities] ... It also allows the 
public to decide which organisations should receive support from the government.

The missing ingredient was data that would enable donors to compare the fundraising activities of charities over time and between organisations. The Commission (p. xxxvii) recommended that financial information requirements about fundraising should be met 'through a sector-specific accounting standard and form of incorporation'. It made the point that most States/Territories lacked the systems necessary to collect the information and make it available to the public in a useable form.

The Industry Commission (1995:205) identified the following problems with the system:

- lack of consistent data collection processes;

- lack of public access to information; and

- lack of standardisation of financial reporting and other information.

The main issue is to define the type and amount of data that would satisfy the donor and other relevant stakeholders. A 2004 survey of NFPs showed that respondents claimed that reporting obligations were excessive. The study concluded, however, that this was not a reason to reduce disclosure, but rather it made the case to ensure appropriate disclosure. '[W]hat is required to be disclosed and by whom' (Woodward and Marshall, 2004:5) was to be more accurately assessed, so that, for example, there would be greater disclosure on some issues such as description of activities, directors' remuneration, and related party transactions. The study recommended that a minimum disclosure standard for all NFP organisations, regardless of size, should include: a summary or concise financial statement, based on a specific accounting standard; a description of the activities, and how they meet the objects of the organisation; and disclosure of directors' remuneration.

For larger organisations, the study (p. 5) recommended that there should be audited accounts and disclosure of the amount (and possibly sources) of public funding. For small organisations (those with an annual income or total annual expenditure of less than $\$ 100,000$ ), ASIC, or a certain percentage of members of the organisation, should have the power to require any organisation to be audited. In addition, the reporting obligations under various Acts - including the Corporations Act 2001 (Cth) and various State Fundraising and Collection Acts - should be unified. Multiple filings should be avoided and low-cost, online searching facilities should be available to maximise transparency. Further, reporting obligations should constitute a 'one-stop' report that would aim to satisfy the needs of various bodies (Woodward and Marshall, 2004:6).

One of the most sensitive elements of a disclosure regime is the fundraising ratio. There are two essential issues. The first is that there is currently no requirement under the Corporations Act to disclose marketing expenditure compared with fundraising receipts and there is considerable inconsistency 
between the Fundraising and Collection Acts of the States and Territories. Attempts to compare fundraising costs are inherently difficult as they may vary, for example, with the popularity of the cause. Revenue from fundraising, gifts, memberships, dues and association fees, and the sale of goods and services needs to be disclosed. This is in addition to disclosure of moneys spent on administration, advertising, promotion, and the like. It is difficult to determine the costs that should be allocated to fundraising, and there are problems such as the apportionment of overheads and campaign costs over the period of fundraising benefit, but standardised accounting methods are achievable. Woodward and Marshall (2004:8) recommended further consideration of the matter by the Australian Accounting Standards Board.

A second element of the fundraising ratio is whether there should be legislative controls on the costs of fundraising. The US and Canadian disclosure regimes for charities specify upper limits on cost of fundraising and on expenditure on advocacy. Interestingly, a recent survey (Muttart, 2004:6) of Canadian attitudes to the latter restriction indicates strong support for charities speaking out on public issues, and 'that existing laws should be relaxed so that charities can speak out more freely on their cause.' The Fundraising Appeals Act in Victoria for example, 'does not specify a percentage of funds raised ... that must always be distributed to the beneficiaries. The approach is based 'on allowing retention of a reasonable proportion of the funds raised' (Consumer Affairs, 2004:9).

The current review of the Act is considering whether the present system is effective in ensuring that 'excessive amounts of proceeds are not retained for administrative costs or whether the Act should specify a percentage of funds that must be distributed to beneficiaries' (Consumer Affairs, 2004:9). The difficulty with such 'standards' is not only that they are arbitrary, but also there are no objective criteria for determining the appropriate limit. Limits may also encourage organisations to underestimate their expenses. Legislation would restrict the ability of high cost organisations to conduct fundraising when there may be legitimate reasons for high fundraising costs for like charities. The Industry Commission considered that legislative controls on the 'acceptable' ratio of costs to fundraising were not desirable (IC, 1995:237). The best policy with respect to standards of performance in fundraising is to allow the donors to make an informed decision.

Subject to further work on definitions of fundraising costs, the ICAA has established a standard of financial reporting that should make an excellent template for any regulator. It recommends that a General Purpose Financial Report (GPFR) should be available in most circumstances (ICAA, 2003:18). The ICAA argued that the following accounting concepts should form the framework of financial reporting for NFPs. Foremost is that the characteristics of the stakeholders determine the information needs. For example, 'the greater the spread of ownership/membership and the greater the extent of separation between management and the owners/members or others with an economic interest in the entity, the more likely it will be that there will exist users dependent on GPFR as a 
basis for making and evaluation resource allocation decisions'. Further, 'the greater the economic or political importance of an entity, the more likely it is that there will exist users dependent on GPFR'. Finally, 'If ... NFPs raise funds from the general public by way of appeal or membership and seek support by way of grants from governments and philanthropic organisations, the NFPs' Financial Reports might be used to make decisions as to where donations or descriptions are directed or whether grants are made'. The ICAA (2003:7) strongly recommended NFPs develop their reports to enlighten the donor in two dimensions, both of which involve Key Performance Indicators (KPIs), namely Process KPIs - those which measure the effectiveness of activities such as fundraising and administration, and Impact KPIs - those which measure the effectiveness of the delivery aspects of the NFP (for example, the number of people assisted or treated, the proportion of people suffering from an affliction assisted by the organisation).

The ICAA also recommended that NFPs report on their three core business segments; generating funds, administering funds and spending funds. This reporting enables comparison of the performance of similar NFPs and meets the needs of donors and grantors. It does not suggest that all NFPs must comply in every respect, but the intention is clear, it wants NFPs to be able to make straightforward statements such as, 'what we are trying to do', 'how we are going about it', and 'what we have achieved during the year' (the complete pro-forma of questions for charities can be found at www.icaa.org.au). These statements combined with the use of various Australian Accounting Standards are likely to provide a sufficient standard for a well-informed donor market. The regulator, in conjunction with the sector, should stimulate further work on standards.

\section{Regulator or Advocate: A Charities Commission or the ASIC?}

Although the accountants can agree on the standard of reporting, the question of who is best to regulate may be more difficult to resolve. The Industry Commission (1995:207) considered several strategies for improving the accountability of charities to donors and the availability of information to the public, including: the establishment of a body responsible for supervision and monitoring charities; the incorporation of charities as public companies under the Corporations Law; and the provision of funds by the Australian Government for the development of an accounting standard specific to the sector.

The Commission argued that the Australian government could require those organisations that wish to raise tax-deductible donations to incorporate in the prescribed way. Linking tax deductibility and this form of incorporation would ensure that donors (and the community in general) would be able to access information about the finances and operations of the charities they support (IC, 1995:218). The state regulators would presumably bring their regulation for fundraising into line with the Commonwealth's. The Woodward and Marshall study reinforced the Commission's themes, recommending a single Commonwealth regulatory regime, with ASIC becoming the new regulator (at least until any new regulator is introduced), and the establishment of a specialist 
unit within ASIC. It also argued that a new independent NFP advisory body should be established to meet this need. A range of support services could be provided at low or no cost - for example, auditing, financial and taxation advice, legal advice, training for Board members, and dispute resolution for stakeholders.

Speaking as Chair of the National Roundtable of Nonprofit Organisations (2004:7) Robert Fitzgerald argued that disclosure

is a key to promoting a more efficient and sustainable environment for nonprofit organisations ... There is a particular need for information to be disclosed in ways that answer the questions that those interested in nonprofit organisations are likely to have ... The Government must be committed to the strong and effective enforcement and facilitation of nonprofit regulation and provide adequate resources to agencies tasked with such responsibilities.

The sector appears to support a uniform standard of regulation, and their advocacy for this is long held and to be applauded. The sector, or at least that part of the industry represented by the Nonprofit Roundtable, however, sees the issue in wider political terms. For example, it recalls the Charities Definition Inquiry recommendation for the creation of an 'independent' commission, such as the Charity Commission in the UK. The body would have responsibility for looking at the overall regulatory regime of charities throughout Australia, and take certain responsibilities from the Australian Taxation Office (Fitzgerald, 2003:8). The sector's keenness to remove responsibility for charities from the ATO stems from its view that, 'the gate-keeping role [of] the Australian Taxation Office ... means that revenue concerns overshadow broader public interest concerns in defining charitable purposes' (Australian Council of Social services, 2001:10).

The sector is concerned that the tax system is being used to control or inhibit the activities or voice of nonprofit organisations.

If governments don't like particular organisations then they don't have to fund them. If the community overall doesn't like the advocacy of a particular organisation, it won't support it - it won't provide money, nor will it provide voluntary effort, and in the end the marketplace will have its effect. We must always guard against regulatory regimes and contracted requirements that seek to limit the ability of any organisation to have a go and have a say (Fitzgerald, 2003:12).

There is some support for Robert Fitzgerald's concerns in a recent survey of NGOs' attitudes to the Australian government. The report concluded that

There has been a serious deterioration in relations between the Federal Government and NGOs to the point where many believe they have been frozen out' and fear they will have their funding withdrawn. The concerns of the NGO sector were heightened by the proposal by the 
Treasurer to disqualify a charity that engages in advocacy that is other than ancillary or incidental. (Maddison, 2004:7)

The sector is well aware of the realpolitik of charity registration. A charity that may have been on the books for many years, but whose aims and methods (not to mention its competence) may presently be almost unrecognisable, has the advantage of incumbency. Governments are very reluctant to be seen to police charities, and to cause one to lose its charity status would be a bold move indeed. The sector knows this, and the few that have been removed from the list in recent years had all but ceased to exist anyway. The 'marketplace will have its effect' but only if it is well informed. The sector seems to want a sympathetic regulator as a counterweight to government. It claims a 'right to special treatment by the community through the tax system' and a 'right to speak out and to influence public policy' (Fitzgerald, 2003:10). The right to special treatment, however, cannot be taken for granted. The price must be a disclosure regime that satisfies the donor. The assertion of the right to special treatment also assumes that there is no ongoing discussion of the legitimacy of charities' purposes and practices. The fact is that the right to speak out and to influence public policy is nowhere under threat, because this 'right' is not granted by the government. It is a longestablished practice secured by a generous public and buttressed by a very vigorous free press.

The sector cannot expect a sympathetic regulator, though it should expect a well-resourced regulator that understands its needs, especially if the sector is faced with the demands of new disclosure standards. In this regard, the Charity Commission for England and Wales (CCEW) has some valuable lessons to teach Australia. The Commission is working towards a standard of disclosure for the sector, and it is assisting the sector and allowing it time to reach an acceptable standard. The Commission's recent survey of 200 large UK charities assessed the extent to which the charities had gone beyond minimum requirements to provide information that accounted fully and transparently for their performance. The Commissioner (CCEW, 2004a:foreword) concluded: 'Our evidence is that the general standard of performance against the transparency and accountability framework is not satisfactory. Whilst there are some very good examples, too many charities in our study did not meet basic requirements'. The Commission is working towards a standard of disclosure called 'Statement of Recommended Practice', which is to be implemented by March 2005 (CCEW, 2004b).

The CCEW appears to have moved the sector in the right direction, but it is clear that there is still some way to go. A similar reform in Australia would take the resources and impetus for reform that comes with a dedicated regulator. The extra-curricular agenda of the sector, however, needs to be resisted. When the sector cries foul over the possible denial of the freedom to lobby, it is likely suggesting that it would prefer a regulator which, as the price of disclosure, becomes an industry advocate. These matters should not come anywhere near the brief of the regulator; it should not be an advocate, or a friend to the sector. Its role is to protect the taxpayers' investment in the sector, and the donors' right to 
know. The CCEW in the UK operates in the context of the Labour government's 'compact' with the community sector. Labour used this device to win the hearts and minds of the community sector at the same time as it handed a great deal of responsibility to it for programs paid for by government. The role of 'partner with government' was taken up with alacrity by the sector. The difficulty is that 'partner' implies something more than a mere contractual partner. For example, the community sector can compete with private-sector providers to deliver services and at the same time have a considerable influence over the nature of the services. The 'compact' allows the community sector to act as both advocate and provider, using public funds in both roles.

The roles of advocate and provider are best separated, to the benefit of the government, the sector, and the recipients of the programs. The Australian Labor Party has begun to use the language of the 'compact' to win the hearts and minds of the sector, but it falls into the same trap of confusing the two roles of the sector, and the means by which each role should be managed. An Australian charities regulator must apply the agreed standards of disclosure and assist the sector to achieve the standard, but no more than that. The political side, the relationship between the sector and the government, should be handled as it would with any other political lobby.

The CCEW is not a model that should be replicated in Australia. Although it brings knowledge and experience to the job of a regulator, it also comes with the baggage of the sector as a long-standing supplicant to government. For example, four Commissioners manage the Charity Commission, three of whom, including the Chief Commissioner, come from the charity sector. In any context, but especially in the context of the UK government's policy of a compact with the sector, the selection of Commissioners hopelessly confuses the lines of accountability and fouls the separation required to protect the public's interest in the sector. The sector's notion of the public interest is, of course, entirely different from that of the sector's claim to represent the 'public interest.' A Commission should be well informed by the sector, as is the ATO or ASIC, but it should not be a creature of the sector. Indeed, it is questionable whether the resources that will be required by the sector to reach the standards of disclosure recommended should be made available through the Commission. It would be best to have a program of institutional support administered by, for example, the Department of Family and Community Services, and leave the Commission as a regulator without the complication of 'assisting' the sector.

\section{Conclusion}

The Australian government could, as a condition of registration for charity status, impose a national standard of transparency and reporting for charities and establish a new regulator independent of the sector. Resources should be found to assist the sector to attain the required standard, and these resources should not be accessed through the regulator. The charity sector does not need a friend as a 
regulator. It is a sector with many friends in government and many supporters. It will do it no good to have a regulator acting as an advocate on its behalf as well.

Regulation does not imply a loss of freedom to speak, nor does it preclude a debate about the proper use of charity funds - for example, for advocacy. The idea of a powerful disclosure regime is to place much of the work of the scrutiny of charities into the hands of the donor. The sector will not be defenceless against the regulator, it is well organised, and has strong links to its donor base and to the political parties.

\section{References}

Australian Consumers' Association (2002), Choice, October, http://www.choice.com.au (Accessed 12 September 2004).

Australian Council of Social Services (2001), 'Submission to Charities Definition Inquiry', http://www.cdi.gov.au/html/public_submissions.htm.

Australian Environment Organisations (2001), 'Submission to Charities Definition Inquiry', http://www.cdi.gov.au/html/public_submissions.htm.

Australian Taxation Office (2001), 'Submission to Charities Definition Inquiry' http://www.cdi.gov.au/html/public_submissions.htm.

Australian Taxation Office (2004a), 'Non-Profit News Service No. 0055', http://www.ato.gov.au/nonprofit/content.asp?doc=/content/32578.htm.

Australian Taxation Office (2004b), 'ATO Compliance Program 2003-04', http://www.ato.gov.au/corporate/content.asp?doc=/content/36405.htm.

Board of Taxation (2003), Consultation on the Definition of a Charity: A Report to the Treasurer, http://www.taxboard.gov.au/content/charities.asp.

Centre of Philanthropy and Nonprofit Studies (2004), 'Tax Deductible Giving in 2000-01', Current Issues Information Sheet 2004/2. Queensland University of Technology.

Charities Definition Inquiry (2001), Report of the Inquiry into the Definition of Charities and Related Organisations, http://www.cdi.gov.au/html/report.htm.

Charity Commission for England and Wales (2004a), Transparency and Accountability (RS8), http://www.charity-commission.gov.uk/tcc/commissioners.asp.

Charity Commission for England and Wales (2004b), Accounting and Reporting by Charities: Statement of Recommended Practice, Exposure Draft for Consultation, June.

Commonwealth Treasurer (2004), 'Final Response to the Charities Definition Inquiry', Press Release, 11 May.

Consumer Affairs Victoria (2004), 'Review of the Fundraising Appeals Act 1998'.

Donation.com.au, http://www.donations.com.au/about.asp (Accessed 12 September 2004).

Fitzgerald, R. (2003), 'Nonprofit Sector Under the Spotlight - Critical Challenges and Vital Choices for Nonprofit Organisations in a Contested Environment', Speech, QUT Centre of Philanthropy, Alumni Anniversary Dinner, 26 November. 
Give.org (BBB Wise Giving Alliance), http://www.give.org (Accessed 12 September 2004).

Givewell, http://www.givewell.com.au (Accessed 12 September 2004).

Industry Commission (1995), Charitable Organisations in Australia, Report no. 45, AGPS, Canberra.

Institute of Chartered Accountants in Australia (2003a), Review of Not-For-Profit Financial and Annual Reporting, http://www.icaa.org.au/upload/download/NFP2003w.pdf

Institute of Chartered Accountants in Australia (2003b), Press Release, 7 May.

Leat, D. (2004), 'What Do Australian Foundations Do - Who Knows and Who Cares?' Australian Journal of Public Administration 63(2):96-105.

Maddison, S., R. Dennis and C. Hamilton (2004), 'Silencing Dissent: Non-government Organisations and Australian Democracy’, The Australia Institute, Discussion Paper Number 65.

Muttart Foundation (2004), Talking About Charities 2004: Candians' Opinions on Charities and Issues Affecting Charities, The Muttart Foundation, Alberta, Canada.

National Roundtable of Nonprofit Organisations (2004), 'Nonprofit Regulation Reform Program’, An Initial Statement, May 7.

Rollason, R. (2003), The Australian Financial Review, 31 July.

Woodward, S. and S. Marshall (2004), Reforming Not-for-Profit Regulation, Centre for Corporate Law and Securities Regulation, The University of Melbourne.

The paper is an extension of a monograph published by the Institute of Public Affairs in October 2004, 'Informed Giving: Ensuring Charities Inform Donors.' My thanks to two anonymous referees for their comments on the manuscript. 